Article

\title{
Exposure to Insecticides Reduces Populations of Rhynchophorus palmarum in Oil Palm Plantations with Bud Rot Disease
}

\author{
Luis Carlos Martínez ${ }^{1, *}$, Angelica Plata-Rueda ${ }^{2}$, Francisco Andrés Rodríguez-Dimaté ${ }^{3}$, \\ Juliana Mendonça Campos ${ }^{4}$, Valdeir Celestino dos Santos Júnior ${ }^{3}{ }^{(0)}$, \\ Gabriela Da Silva Rolim ${ }^{4}$, Flavio Lemes Fernandes ${ }^{2}\left(\mathbb{D}\right.$, Wiane Meloni Silva ${ }^{5}$, \\ Carlos Frederico Wilcken ${ }^{6}{ }^{\mathbb{D}}$, José Cola Zanuncio ${ }^{3}$ and José Eduardo Serrão ${ }^{1}$ \\ 1 Departamento de Biologia Geral, Universidade Federal de Viçosa, Viçosa 36570-000, Minas Gerais, Brazil; \\ jeserrao@ufv.br \\ 2 Instituto de Ciências Agrarias, Universidade Federal de Viçosa, Rio Paranaíba 38810-000, Minas Gerais, \\ Brazil; angelicaplata@yahoo.com.mx (A.P.-R.); flaviofernandes@ufv.br (F.L.F.) \\ 3 Departamento de Entomologia, Universidade Federal de Viçosa, Viçosa 36570-000, Minas Gerais, Brazil; \\ ingpachogro@hotmail.com (F.A.R.-D.); scvaldeir@gmail.com (V.C.d.S.J.); zanuncio@ufv.br (J.C.Z.) \\ 4 Departamento de Fitotecnia, Universidade Federal de Viçosa, Viçosa 36570-000, Minas Gerais, Brazil; \\ mendonca.campos@yahoo.com.br (J.M.C.); gabrielasrolim@gmail.com (G.D.S.R.) \\ 5 Departamento de Ciência Florestal, Universidade Federal de Viçosa, Viçosa 36570-000, Minas Gerais, Brazil; \\ wianems@yahoo.com.br \\ 6 Departamento de Proteção de Plantas, Universidade Estadual Paulista, Botucatu 18603-970, São Paulo, \\ Brazil; cwilcken@fca.unesp.br \\ * Correspondence: lc.martinez@outlook.com; Tel.: +55-31-3899-4012
}

Received: 6 March 2019; Accepted: 27 March 2019; Published: 19 April 2019

check for updates

\begin{abstract}
The South American palm weevil (SAPW), Rhynchophorus palmarum Linnaeus (Coleoptera: Curculionidae) is the main pest of Elaeis guineensis and damages palm trees with bud rot disease in the Americas. The effects of six neurotoxic insecticides (abamectin, carbaryl, deltamethrin, fipronil, imidacloprid and spinosad) were evaluated against SAPW for toxicity, survival, reproduction, and mortality. Abamectin $\left(\mathrm{LC}_{50}=0.33 \mathrm{mg} \mathrm{mL}{ }^{-1}\right)$, Carbaryl $\left(\mathrm{LC}_{50}=0.24 \mathrm{mg} \mathrm{mL}^{-1}\right)$, deltamethrin $\left(\mathrm{LC}_{50}=0.17 \mathrm{mg} \mathrm{mL}^{-1}\right)$, and fipronil $\left(\mathrm{LC}_{50}=0.42 \mathrm{mg} \mathrm{mL}^{-1}\right)$ were the most toxic to SAPW. Adult survival was 95\% without exposure to insecticides, decreasing to $78-65 \%$ in insects treated with the $\mathrm{LC}_{25}$ and $49-35 \%$ in insects exposed to $\mathrm{LC}_{50}$. Sublethal doses of carbaryl, fipronil and imidacloprid showed significant effect on the reproduction of this insect. Mortality of SAPW populations caused by insecticides had similar effects in the laboratory and field conditions. The results suggest that carbaryl, deltamethrin, fipronil, and imidacloprid caused significantly higher mortality as compared to the control in SAPW and may be used to control its populations in oil palm trees where bud rot appears as the key disease for SAPW attraction and infestation.
\end{abstract}

Keywords: effects on reproduction; insect pest-disease association; insecticide efficacy; neurotoxicity; pest control; survivorship

\section{Introduction}

The South American palm weevil (SAPW), Rhynchophorus palmarum Linnaeus (Coleoptera: Curculionidae) is the most destructive insect of oil palm (Elaeis guineensis Jacquin) in the Americas. The SAPW also damages other palm tree species as Attalea maripa (Aubl. Mart.), Cocos nucifera (L.), Elaeis oleifera (Kunth), Jessenia bataua (Mart.), Mauritia flexuosa (L.F.), and Phoenix sylvestris (L.) [1,2]. This insect 
has bimodal activity habits, with pest activity peaks at 07:00 to 11:00 h and 17:00 to 19:00 $\mathrm{h}[3,4]$. The life cycle of the SAPW is 164 days (egg 2-5, larva 45-70, pupa 25-45, and adult 60-85) [1,3]. In Colombia, SAPW can reach high infestations in palms during different steps of the Bud Rot disease (Phytophthora palmivora E.J. Butler) progression [5].

The causal agent of bud rot disease, P. palmivora, is widespread in oil palm plantations in the Americas. The sporangia develop in the meristem of the palm trees, causing necrotic lesions in the younger leaves which cause those leaves to rot and fall, thus reducing foliar area, fruit quality and oil production [6,7]. In addition, leaves decomposing in the oil palm canopy produce volatile compounds through fermentation that attracts SAPW adults [8]. Females of the SAPW drill into the rotting or juicy leaf, where they lay their eggs, and the hatching larvae begin feeding before moving to the plant meristem [1,5]. Oil palm can stop growing and plant death occurs because the meristem is consumed by larvae [1,5] and this tissue is not recoverable in monocots such as E. guineensis.

The SAPW-bud rot disease association causes death and total loss of palm trees [5]. This association has destroyed entire oil palm plantations in several countries including Brazil, Colombia, Ecuador, and Suriname [6-8]. In this context, the combined impact of the SAPW and bud rot disease represents a phytosanitary emergency in the Americas due to high infestation of oil palm plantations. Several cases of other insect pest-disease associations were reported in E. guineensis with Acharia fusca Stoll (Lepidoptera: Limacodidae) and Stenoma impressella Busck (Lepidoptera: Elachistidae) with Pestalotiopsis fungal complex [9-11], Haplaxius crudus Van Duzee (Hemiptera: Cixiidae) with fatal yellowing [12], and SAPW with the red-ring nematode disease caused by Bursaphelenchus cocophilus Cobb (Parasitaphelenchidae) [13].

The capture of SAPW adults with traps using the aggregation pheromone (E-6-Methyl-2-hepten-4-ol) is the main control method for this insect in oil palm plantations [14]. Massive traps pheromone system is efficient in crops but may not protect palm trees with bud rot disease from SAPW infestations [6]. Biological control with the parasitoids Billaea rhynchophorae Blanchard and Paratheresia menezesi Townsend (Diptera: Tachinidae) have potential for managing SAPW, but mass rearing methods for these insects are still in development $[15,16]$.

Application of chemical insecticides is an efficient method for managing oil palm pest populations [17,18]. Other palm tree pests such as Rhynchophorus cruentatus Fabricius and Rhynchophorus ferrugineus Oliver (Coleoptera: Curculionidae) have been controlled with insecticides as an effective alternative [19,20]. Active neurotoxic ingredients such as abamectin, carbaryl, deltamethrin, fipronil, imidacloprid, and spinosad have different modes of action and are registered with the environmental regulatory agency United States, the Environmental Protection Agency (EPA) [21,22]. Abamectin affects the neuronal membrane of insects and acts as an antagonist to the $\gamma$-aminobutyric acid (GABA)-gated chloride channel [23-25]. Carbaryl inhibits acetylcholinesterase and thereby leads to the accumulation of the neurotransmitter acetylcholine, increasing stimulation of the cholinergic postsynaptic receptors [26-28]. Deltamethrin acts in the axonal membranes and prevent the closure of the voltage-gated sodium channels [29-31]. Fipronil disrupts blocking the GABA chloride channel and glutamate-gated chloride $(\mathrm{GluCl})$ channels [31-34]. Imidacloprid interferes with the transmission of nerve impulses in insects by irreversible and specific binding to nicotinic acetylcholine receptors [35-37]. Spinosad is neurotoxic and it binds to the specific nicotinic acetylcholine and GABA receptors [38-40]. These novel insecticides can be used against the oil palm pest because of their suitability for integrated pest management (IPM) programs.

In this study, we evaluated the toxicity, survivorship, and impact on reproduction caused by neurotoxic insecticides on the SAPW in order to contribute to the development of strategies for controlling this insect pest, mainly in areas where bud rot disease appears as the key for SAPW attraction and infestation. 


\section{Materials and Methods}

\subsection{Insects}

In the field, 347 SAPW adults $\left(\sigma^{7}=128, \phi=219\right)$ were collected with traps in 7-year old commercial oil palm plantations in the county of Puerto Wilches, State of Santander, Colombia (07 $25^{\prime}$ N, $\left.73^{\circ} 57^{\prime} \mathrm{W}\right)$. Traps were made of plastic containers $(20 \mathrm{~L})$ with two side holes on the top $(8 \times 12 \mathrm{~cm})$. A mixture of vegetable substrate ( $250 \mathrm{~g}$ of sugarcane $+250 \mathrm{~mL}$ water in the ratio 1:1) and $5 \mathrm{~mL}$ of aggregation pheromone (E-6-Methyl-2-hepten-4-ol) obtained from the Chemical Products Laboratory of the National Institute of Agricultural Research (INRA, Versailles, France) was placed in each trap in a polystyrene bag. The captured insects were placed in plastic boxes $(50 \times 50 \times 70 \mathrm{~cm})$ with a perforated lid for ventilation and were transported to the agronomy laboratory of the University of Peace (UNIPAZ, Barrancabermeja, Santander, Colombia) to establish a mass rearing in the laboratory. Males and females of the SAPW were isolated in plastic trays $(60 \mathrm{~cm}$ long $\times 40 \mathrm{~cm}$ wide $\times 30 \mathrm{~cm}$ high $)$ which contained E. guineensis meristem. To collect the eggs, 900 oviposited eggs on the surface of the meristem were collected every $24 \mathrm{~h}$ and placed in Petri dishes $(90 \times 15 \mathrm{~mm})$ containing a cotton saturated with distilled water. After hatching, first-instar larvae $(n=700)$ were placed individually in plastic boxes $(10 \times 20 \mathrm{~cm})$ covered with cotton and fed every $24 \mathrm{~h}$ with sugarcane [1]. Larvae and pupae were maintained in an incubator $\left(28 \pm 2{ }^{\circ} \mathrm{C}, 75-85 \% \mathrm{RH}\right.$, and a photoperiod of $12 \mathrm{~h}$ [Light:Dark]) until adult emergence. Emerged adults were placed in plastic trays $(60 \mathrm{~cm}$ long $\times 40 \mathrm{~cm}$ wide $\times 30 \mathrm{~cm}$ high) and fed on E. guineensis meristem. SAPW adults were kept in the laboratory $\left(28 \pm 2{ }^{\circ} \mathrm{C}, 75-85 \% \mathrm{RH}\right.$, and a photoperiod of $12 \mathrm{~h}$ [L:D]). Healthy SAPW adults with $72 \mathrm{~h}$-old (emerged after to escape of the pupal cell) were used in the bioassays.

\subsection{Concentration-Mortality Bioassay}

Neurotoxic insecticides with different action modes and insecticidal contact activities (according to the commercial formulations) were used in all bioassays. The following insecticides abamectin (Vertimec ${ }^{\circledR}$, Syngenta, Basel, Swaziland), $18 \mathrm{~g} \mathrm{~L}^{-1}$; carbaryl (Carbaril ${ }^{\circledR}$, Drexel Chemical, Memphis, TN, USA), $480 \mathrm{~g} \mathrm{~L}^{-1}$; deltamethrin (Decis ${ }^{\circledR}$ Bayer, Leverkusen, North Rhine-Westphalia, Germany), $25 \mathrm{~g} \mathrm{~L}^{-1}$; fipronil (Regent ${ }^{\circledR}$, Bayer, Leverkusen, North Rhine-Westphalia, Germany), $200 \mathrm{~g} \mathrm{~L}^{-1}$; imidacloprid (Confidor ${ }^{\circledR}$, Cyanamid, Wayne, NJ, USA), $200 \mathrm{~g} \mathrm{~L}^{-1}$; and spinosad (Tracer ${ }^{\circledR}$, Dow Agrosciences, Zionsville, IN, USA), $120 \mathrm{~g} \mathrm{~L}^{-1}$ were diluted in $1 \mathrm{~L}$ of distilled water to obtain the stock solutions. After 30 min of stock solution preparation, six concentrations of each insecticide were then prepared and used to assess the insecticide toxicity and determine relevant toxicological endpoints; a dilution series of concentrations $\left(0.062,0.125,0.25,0.5,1 \mathrm{mg} \mathrm{mL}^{-1}\right.$, and $\left.2 \mathrm{mg} \mathrm{mL}^{-1}\right)$ was used to determine the concentration-mortality relationship and lethal concentrations $\left(\mathrm{LC}_{25}, \mathrm{LC}_{50}, \mathrm{LC}_{75}\right.$, and $\left.\mathrm{LC}_{90}\right)$. Distilled water was used as a control. Subsequently, each insecticide solution $(10 \mu \mathrm{L})$ was applied to the thorax of 100 SAPW adults (males/females, 1 ratio) using a micropipette (Eppendorf ${ }^{\circledR} 1-10 \mu \mathrm{L}$, Hamburg, Deutschland). The exposed insects were placed individually in polystyrene boxes $(12 \times 15 \mathrm{~cm})$ and maintained in a photoperiod of $12 \mathrm{~h}$ [L:D]. Oil palm meristem blocks were provided as food and sectioned $1 \mathrm{~h}$ before insecticide exposure. Three replicates with 100 adults each were used for each of the six concentrations tested, following a completely random design. Mortality was registered after insecticide exposure over $2 \mathrm{~d}$.

\subsection{Time-Mortality Bioassay}

The time-mortality bioassays for the SAPW using the insecticide concentrations obtained from the concentration-mortality bioassay were carried out to determine the lethal toxicity. Adults of the SAPW were exposed to $\mathrm{LC}_{25}$ and $\mathrm{LC}_{50}$ of each insecticide, as determined in the toxicity bioassay, mortality was recorded after every $12 \mathrm{~d}$. Exposure procedures, conditions, and number of insects were the same as those described above for the toxicity test. Three replications with 50 adults each were used to verify the insecticide concentrations, following a completely random design. 


\subsection{Insecticide Effects on Reproduction}

Adults of the SAPW were isolated in plastic containers $(25 \times 25 \times 25 \mathrm{~cm})$, containing E. guineensis meristem. The calculated lethal concentration $\left(\mathrm{LC}_{25}\right)$ of each insecticide was topically applied to the thorax of the insects (males/females, 1 ratio). Distilled water was used as a control. A total twenty-five pairs of SAPW adults were individually evaluated every day until the female died. Each adult pair was checked daily and the eggs were counted, collected, and transferred into new glass containers. Meristem on which the adults had been feeding was then inspected and eggs were collected per day. Then, copulation (mated females) was recorded and females that had not produced eggs during longevity were considered to have failed to mate. Also, fecundity (average number of eggs produced/mated females) and viability (eggs hatched)/total eggs (hatched + unhatched eggs) was calculated. The number of offspring/females was calculated as: percentage of copulation $\times$ fecundity $\times$ viability.

\subsection{Field Assays in Palm Trees with Bud Rot Disease}

The bioassay was conducted in 7-year-old commercial oil palm plantations ( $\mathrm{cv}$ 'Tenera' $\times$ 'Deli Ghana') in the county of Puerto Wilches (Santander, Colombia), with an average temperature of $28.46^{\circ} \mathrm{C}$, $75-92 \%$ relative humidity, $1580-2155 \mathrm{~h}$ annual sunshine, and $2283 \mathrm{~mm}$ annual rainfall. In these natural conditions, 420 palm trees with early symptoms of bud rot disease were selected [41] where high infestations of the SAPW have been found in previous studies [5]. Adults of this insect (males/females, 1 ratio) were used for each treatment in the controlled field test. For each palm tree, 50 adults were placed on the canopy, above the meristem and isolated with a nylon cage $(0.5 \times 0.5 \times 1.20 \mathrm{~m})$ for $15 \mathrm{~d}$ to ensure the different developmental stages of SAPW. Each insecticide at the calculated lethal concentration $\left(\mathrm{LC}_{90}\right)$ as well as the control (distilled water) was used as treatment with four replications. Treatments were applied at the day 15th day after setting the cage, where adults had a reproductive period and subsequently, populations were obtained at different life stages. Applications of $1 \mathrm{~L}$ of insecticide solution per canopy were made by a hand sprayer (Sampoorti Agrocare ${ }^{\circledR}$, New Delhi, India, $16 \mathrm{~L}$ capacity). The palm trees were cut, the trunk carefully dissected with a chainsaw (MS 880 Stihl Magnum ${ }^{\circledR}$, Orlando, FL, USA), and checked with a magnifying glass for the presence of the SAPW in the stages of larva, pupa, and adult alive and dead, which were counted. For group of palms cut each $15 \mathrm{~d}$, mortality of the SAPW caused by insecticides was recorded each $15 \mathrm{~d}$ during two months with an experimental design in randomized blocks.

\subsection{Statistical Analysis}

Concentration-mortality data were subjected to Probit analysis, generating concentration-mortality curve [42]. Time-mortality bioassay data were submitted to survival analysis using the Kaplan-Meier estimator (log-rank method) with the Origin Pro v 9.1 program [43]. The number of surviving SAPW adults at the end of the experiment was treated as censored data. Insecticidal effects on reproduction (percentage of copulation, fecundity, viability, and offspring/female) were analyzed by one-way ANOVA. For mortality in field conditions, a Kolmogorov-Smirnov test verified the data normality to meet the normality assumptions and ANOVA was conducted as a mixed model. A Tukey's Honestly Significant Difference (HSD) test was also used for comparison of means at the $5 \%$ significance level. Mortality data were summarized in percentages and all values presented as mean \pm SEM. Concentration-mortality, reproduction, and mortality data in field conditions were analyzed using SAS User software (v. 9.0) for Windows [44].

\section{Results}

\subsection{Toxicity}

The concentration-mortality model used was suitable $\left(\chi^{2} ; p<0.001\right)$ confirming the toxicity of each insecticide to SAPW and allowing the estimates of the desired toxicological endpoints for subsequent 
use (Table 1). For the $\mathrm{LC}_{50}$ estimated value, bioassay indicated that deltamethrin with $\mathrm{LC}_{50}=0.17$ (0.03-0.29) $\mathrm{mg} \mathrm{mL}^{-1}$ and carbaryl with $\mathrm{LC}_{50}=0.24(0.08-0.33) \mathrm{mg} \mathrm{mL}^{-1}$ were the most toxic insecticides to the SAPW adults followed by abamectin with $\mathrm{LC}_{50}=0.33(0.26-0.61) \mathrm{mg} \mathrm{mL}^{-1}$, fipronil with $\mathrm{LC}_{50}=0.42(0.40-0.44) \mathrm{mg} \mathrm{mL}^{-1}$, spinosad with $\mathrm{LC}_{50}=0.54(0.19-0.62) \mathrm{mg} \mathrm{mL}^{-1}$, and imidacloprid with $\mathrm{LC}_{50}=0.66(0.56-0.84) \mathrm{mg} \mathrm{mL}^{-1}$. Mortality remained $<1 \%$ in the control.

Table 1. Lethal concentrations of six insecticides on Rhynchophorus palmarum adults obtained from Probit analysis. For all insecticides, chi-square $\left(\chi^{2}\right)$ for lethal concentrations and fiducial limits based on a log scale were statistically significant at the $p<0.001$ level.

\begin{tabular}{|c|c|c|c|c|c|}
\hline Insecticides & $\begin{array}{c}\text { Lethal } \\
\text { Concentration }\end{array}$ & $\begin{array}{l}\text { Estimated Value } \\
\qquad\left(\mathrm{mg} \mathrm{mL}^{-1}\right)\end{array}$ & $\begin{array}{l}\text { Confidence Interval } \\
\qquad\left(\mathrm{mg} \mathrm{mL}^{-1}\right)\end{array}$ & $\begin{array}{l}\text { Slope } \\
( \pm \text { SE) }\end{array}$ & $x^{2}$ \\
\hline \multirow{4}{*}{ Abamectin } & 25 & 0.22 & $0.06-0.39$ & \multirow{4}{*}{$1.21( \pm 0.11)$} & \multirow{4}{*}{8.731} \\
\hline & 50 & 0.33 & $0.26-0.51$ & & \\
\hline & 75 & 0.43 & $0.19-1.57$ & & \\
\hline & 90 & 0.52 & $0.35-2.96$ & & \\
\hline \multirow{4}{*}{ Carbaryl } & 25 & 0.17 & $0.06-0.19$ & \multirow{4}{*}{$3.15( \pm 2.23)$} & \multirow{4}{*}{46.71} \\
\hline & 50 & 0.24 & $0.08-0.33$ & & \\
\hline & 75 & 0.41 & $0.31-0.52$ & & \\
\hline & 90 & 0.56 & $0.46-0.74$ & & \\
\hline \multirow{4}{*}{ Deltamethrin } & 25 & 0.06 & $0.02-0.18$ & \multirow{4}{*}{$3.11( \pm 1.95)$} & \multirow{4}{*}{21.28} \\
\hline & 50 & 0.17 & $0.03-0.29$ & & \\
\hline & 75 & 0.28 & $0.14-0.46$ & & \\
\hline & 90 & 0.38 & $0.25-0.65$ & & \\
\hline \multirow{4}{*}{ Fipronil } & 25 & 0.35 & $0.32-0.37$ & \multirow{4}{*}{$3.94( \pm 1.49)$} & \multirow{4}{*}{64.71} \\
\hline & 50 & 0.42 & $0.40-0.44$ & & \\
\hline & 75 & 0.50 & $0.48-0.52$ & & \\
\hline & 90 & 0.57 & $0.55-0.60$ & & \\
\hline \multirow{4}{*}{ Imidacloprid } & 25 & 0.39 & $0.20-0.49$ & \multirow{4}{*}{$2.94( \pm 1.92)$} & \multirow{4}{*}{34.61} \\
\hline & 50 & 0.66 & $0.56-0.84$ & & \\
\hline & 75 & 0.94 & $0.38-1.92$ & & \\
\hline & 90 & 1.19 & $0.96-1.78$ & & \\
\hline \multirow{4}{*}{ Spinosad } & 25 & 0.26 & $0.15-0.37$ & \multirow{4}{*}{$1.37( \pm 0.19)$} & \multirow{4}{*}{10.22} \\
\hline & 50 & 0.54 & $0.19-0.62$ & & \\
\hline & 75 & 0.91 & $0.78-1.04$ & & \\
\hline & 90 & 1.35 & $1.21-1.53$ & & \\
\hline
\end{tabular}

\subsection{Survival Analysis}

The survivorship was recorded when the pest was exposed from $12 \mathrm{~d}$ to the various insecticides each applied at different lethal concentrations (Figure 1). The survival analysis of the data from the SAPW adults exposed to lethal concentration $\mathrm{LC}_{50}$ of each insecticide indicated differences (log-rank test, $\chi^{2}=59.88, \mathrm{df}=6, p<0.001$ ). Survivorship was $95.1 \%$ in the control, decreasing to $47.4 \%$ with abamectin, $45.7 \%$ with carbaryl, $35.8 \%$ with deltamethrin, $41.8 \%$ with fipronil, $49.3 \%$ with imidacloprid, and $45.1 \%$ with spinosad. Survivorship of the SAPW exposed to lethal concentration $\mathrm{LC}_{25}$ of each insecticide showed differences (log-rank test, $\chi^{2}=51.03, \mathrm{df}=6, p<0.001$ ). Survivorship was $96.8 \%$ in the control, decreasing to $74.1 \%$ with abamectin, $65.8 \%$ with carbaryl, $76.7 \%$ with deltamethrin, $76.1 \%$ with fipronil, $78.6 \%$ with imidacloprid, and $78.3 \%$ with spinosad. 

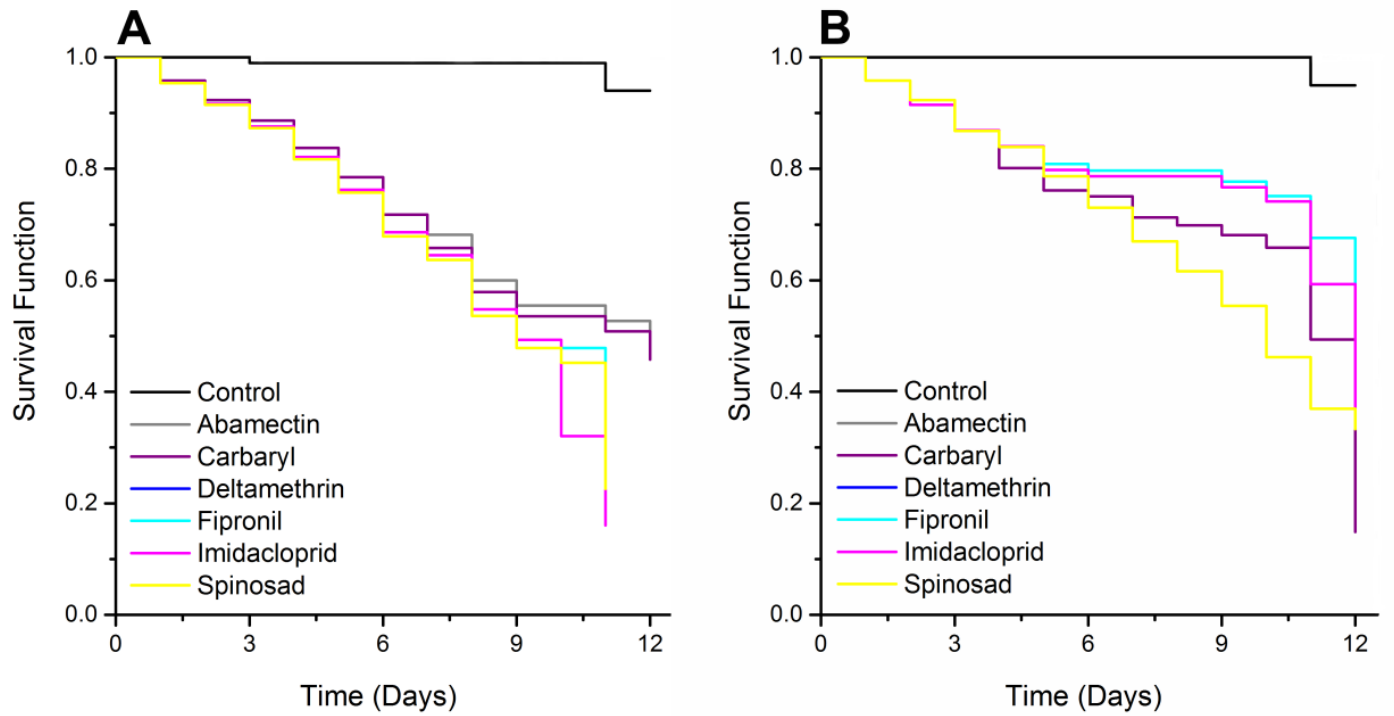

Figure 1. Survival curves of Rhynchophorus palmarum adults exposed to insecticides subjected to survival analyses using the Kaplan-Meier estimators' log-rank test. Lethal concentration (A) LC $_{50}$ $\left(\chi^{2}=59.88 ; p<0.001\right)$ and $(\mathbf{B}) \mathrm{LC}_{25}\left(\chi^{2}=51.03 ; p<0.001\right)$.

\subsection{Insecticide Effects on Reproduction}

The effects caused by six insecticides on reproductive factors of the SAPW, such as percentage of copulation, fecundity, eggs viability and number of offsprings per females, were determined (Figure 2). The percentage of copulation of the SAPW was different between insecticides tested with concentrations estimated for the $\mathrm{LC}_{25}$ values $\left(\mathrm{F}_{6,24}=9.46, p<0.05\right)$. The percentage of copulation was high when the insects were exposed to carbaryl (88.9\%), control group (87.6\%), abamectin (86.7\%), and spinosad $(85.5 \%)$ and less with deltamethrin $(77.3 \%)$, fipronil $(72.2 \%)$, and imidacloprid $(72.1 \%)$. The fecundity differed between the insecticides tested $\left(\mathrm{F}_{6,24}=11.73, p<0.05\right)$. The number of eggs per female was high with deltamethrin $(886 \pm 6.2)$, abamectin $(791 \pm 11)$, and the control group $(762 \pm 12)$ and significantly lower with imidacloprid $(436 \pm 26)$ and fipronil $(414 \pm 29)$. The eggs viability was among different insecticides tested $\left(\mathrm{F}_{6,24}=7.85, p<0.05\right)$. Eggs viability was high in the control group $(96.3 \%)$, following by imidacloprid $(86.7 \%)$, abamectin $(85.7 \%)$, deltamethrin $(85.1 \%)$, carbaryl $(84.4 \%)$, and spinosad $(84.5 \%)$. Insecticides reduced the SAPW offspring per female $\left(\mathrm{F}_{6,24}=11.52, p<0.05\right)$, being high in deltamethrin (777 \pm 76$)$, control group $(691 \pm 51)$, abamectin $(675 \pm 52)$, and spinosad (646 \pm 24$)$.

\subsection{Mortality in Field Conditions}

The mortality effects caused by the tested insecticides on the SAPW larvae were different in the field conditions, using the previously estimated concentrations for the $\mathrm{LC}_{90}$ values $\left(\mathrm{F}_{6,139}=76.29 ; p<0.05\right)$. Fipronil and deltamethrin caused mortalities of $99.6 \pm 0.2 \%$ and $95.9 \pm 2.1 \%$, respectively, followed by mortalities by imidacloprid, carbaryl, abamectin, and spinosad of $87.5 \pm 5.1 \%, 84.2 \pm 4.6 \%, 82.6 \pm 1.9 \%$, and $80.9 \pm 4.9 \%$, respectively. Mortality never exceeded $3.16 \pm 1.1 \%$ in the control (Figure 3A). Mortality of the SAPW pupae differed between insecticides in the field according to the $\mathrm{LC}_{90}$ values $\left(\mathrm{F}_{6,139}=53,06\right.$; $p<0.05$ ). Fipronil, imidacloprid, and carbaryl caused mortality rates of $90.6 \pm 5.9 \%, 87.8 \pm 4.3 \%$, and $87.5 \pm 5.1 \%$, respectively, while deltamethrin, abamectin and spinosad caused lower mortality of $50.8 \pm 7.6 \%, 37.8 \% \pm 7.5 \%$, and $34.7 \pm 7.7 \%$, respectively. Mortality did not exceed $2.66 \pm 1.6 \%$ in the control (Figure 3B). Mortality of the SAPW adults differed between insecticides according to the estimated $\mathrm{LC}_{90}\left(\mathrm{~F}_{6,139}=35.18, p<0.05\right)$. Fipronil, carbaryl, and deltamethrin caused mortality of $79.7 \pm 1.4 \%, 76.3 \pm 3.3 \%$, and $68.2 \pm 2.9 \%$, respectively, followed by abamectin with $59.4 \pm 9.4 \%$. Imidacloprid and spinosad caused lower mortality with $53.5 \pm 1.8 \%$ and $51.5 \pm 4.4 \%$, respectively. Mortality never exceeded $5.75 \pm 0.8 \%$ in the control (Figure 3C). 

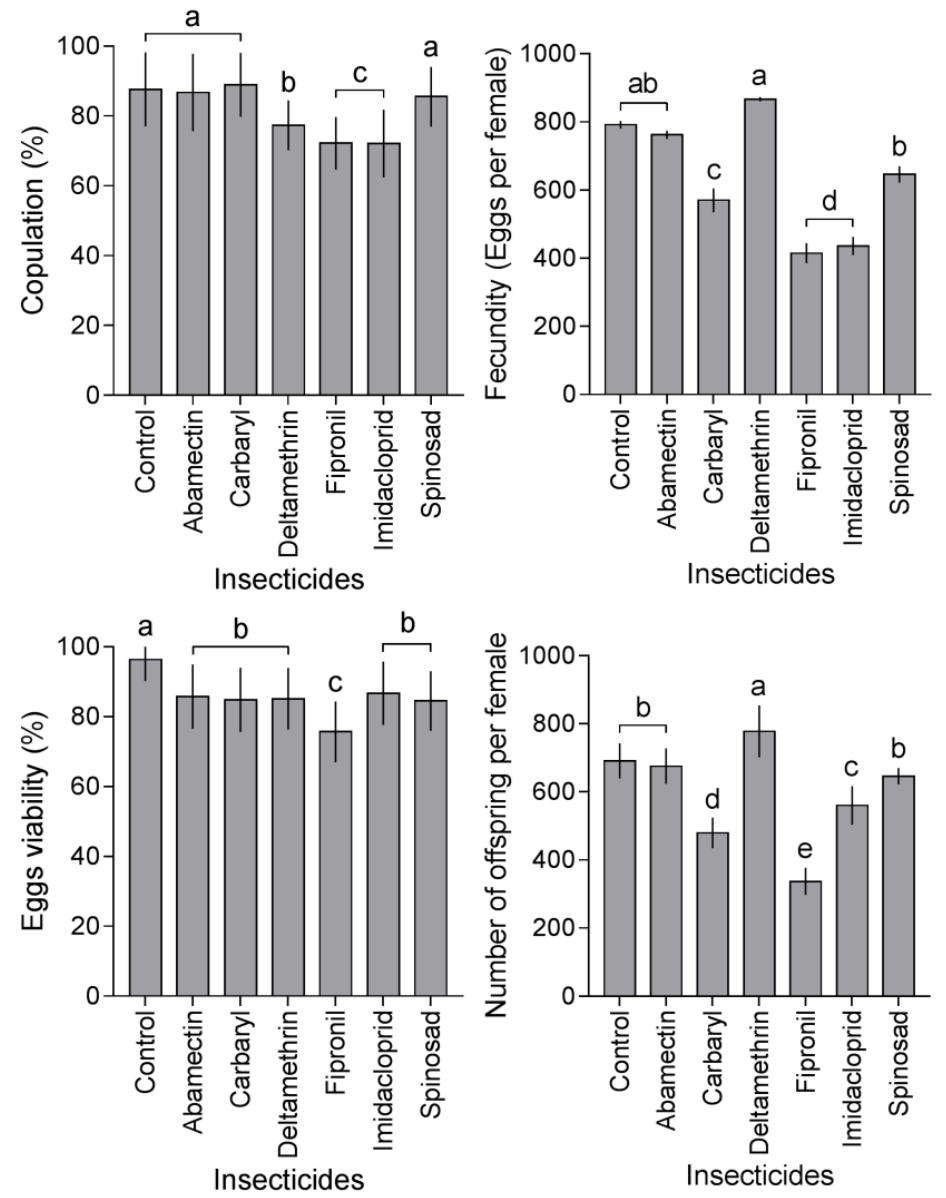

Figure 2. Effects on the reproduction of Rhynchophorus palmarum caused by sublethal concentration $\mathrm{LC}_{25}$ of the six insecticides: percentage of copulation, fecundity, eggs viability and offspring/female (Mean \pm SEM). In each graph, values in the same column with different letters show significant differences by Tukey's HSD test at the $p<0.05$ level.
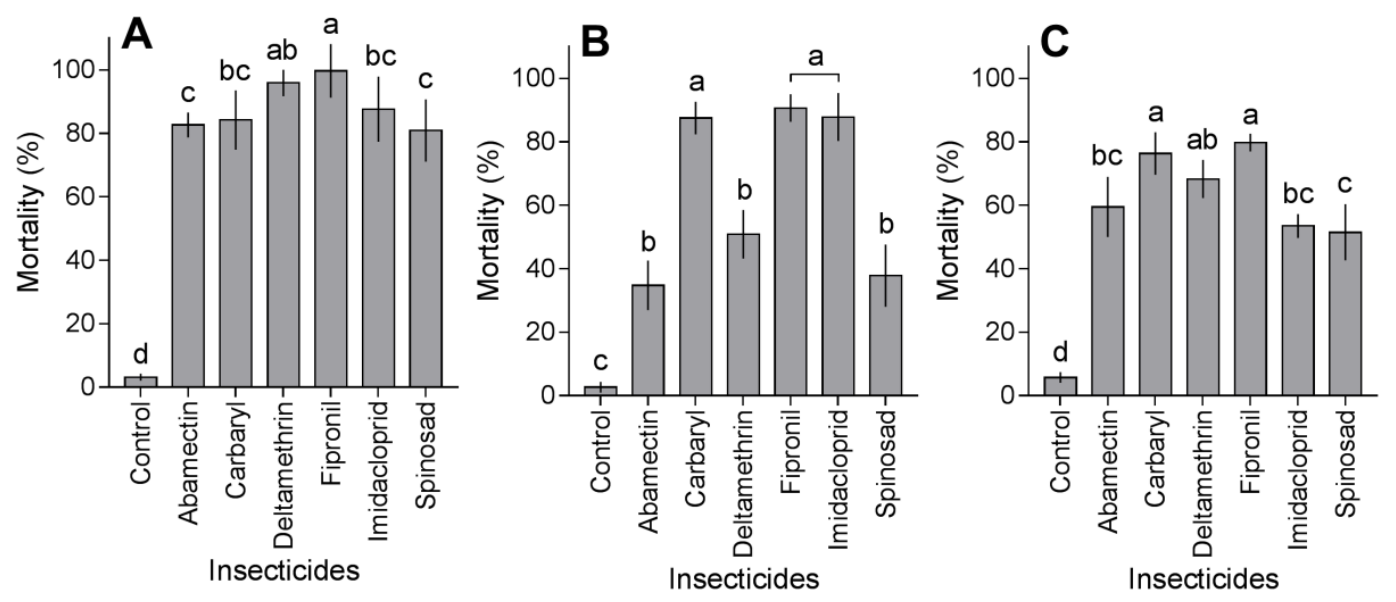

Figure 3. Mortality of Rhynchophorus palmarum by insecticides to level $\mathrm{LC}_{90}$ application on palm trees with bud rot disease: larvae (A), pupae (B) and adults (C). Treatments means (percent mortality \pm SEM) with different letters show significant differences by Tukey's HSD test at the $p<0.05$ level. 


\section{Discussion}

The use of various neurotoxic insecticides was effective in causing mortality, compromising survivorship, and reducing reproduction of the SAPW. These insecticides have the potential to be an effective component of an IPM program, mainly in oil palm plantations with bud rot disease.

The toxicity of six insecticides to the SAPW was determined from the bioassays performed under laboratory and field conditions. The insecticides deltamethrin, carbaryl, abamectin, fipronil, spinosad and imidacloprid were toxic to adult SAPWs and have a strong effect through topical application. The SAPW individuals exposed to high concentrations of each insecticide $\left(\mathrm{LC}_{50}\right.$ and $\left.\mathrm{LC}_{90}\right)$ displayed altered locomotor activity. In some individuals, the constant paralysis at concentrations close to the $\mathrm{LC}_{50}$ and no sign of recovery show the effect of insecticides on the nervous system of the insect. In this study, the concentration-mortality bioassay indicated that evaluated concentrations of imidacloprid followed by spinosad were less toxic to the SAPW. However, insecticides such as abamectin, carbaryl, deltamethrin and fipronil can be used on the SAPW for their different modes of action and applied in rotation, thus avoiding the effects of insecticide resistance.

Survival analysis indicated that a significant proportion of variation in SAPW survival during our trials could be attributed to action mode differences among insecticides. However, extended periods of exposure to insecticides were necessary to induce mortality in the SAPW. In this study, the comparative effects on the SAPW between the neurotoxic insecticides were observed at various time points. The speed with which the insecticide acts on the insect is useful because can define the lethal effect quickly and consequently, essential to protect crops, especially when the target insect is a vector of dangerous pathogens as in the case of the SAPW [3,5,45]. Some insecticides cause cessation of feeding long before the target insects actually dies. However, a quick-acting insecticide can be essential for impregnation of the palm meristem; in this case, the weevils were able to feed, even if they died later. Neurotoxic insecticides and other toxic compounds can reduce injuries to oil palm by insect pests such as Atta sexdens Linnaeus (Hymenoptera: Formicidae) [46], Demotispa neivai Bondar (Coleoptera: Chrysomelidae) [47], Leptopharsa gibbicarina Froeschner (Hemiptera: Tingidae) [48], and Strategus aloeus Linnaeus [25].

Sublethal effects caused with $\mathrm{LC}_{25}$ of each insecticide on the reproduction of the SAPW were observed. Exposure to deltamethrin, fipronil, and imidacloprid affects the sexual behavior of male and female of this insect and causes a significant reduction in mating among pairs of virgin adults. In this case, adults disrupted mating for a long time period under laboratory conditions and some individuals treated were seen to recover the locomotor activity and their ability to mate. Various studies have reported the sexual behavior in insects after insecticide exposure, affecting the ability of male, sex pheromone signal detection, and sustained oriented flight [49-51]. With regard to fecundity, a smaller egg quantity was observed in females of the SAPW after carbaryl, fipronil, imidacloprid and spinosad exposure, although these females were stimulated (hormoligosis) to oviposit more eggs with deltamethrin. Effects on fecundity were studied in Choristoneura fumiferana Clemens (Lepidoptera: Tortricidae) exposed to carbaryl [52], Helicoverpa armigera Hübner (Lepidoptera: Noctuidae) exposed to spinosad [53], Nephotettix virescens Distant (Hemiptera Cicadellidae) exposed to imidacloprid [54], and Plutella xylostella Linnaeus (Lepidoptera: Plutellidae) exposed to fipronil [55], while hormoligosis was reported in Nilaparvata lugens Stål (Hemiptera: Delphacidae) exposed to pyrethroids [51]. Effects on egg viability were found and can be attributed to the different modes of action of these insecticides. In this context, insecticides cause abnormal egg hatching, disrupt hormonal balance, and alter embryonic developmental, compromising egg survival for various insects [46,56,57]. The results suggest that neurotoxic insecticides have high impact on the reproduction of the SAPW, affecting the olfactory response, fecundity, egg viability and offspring of this insect.

The lethal effect of the insecticides on the SAPW in palm trees with bud rot disease in the field was consistent with those observed in the laboratory. Fipronil, carbaryl, and deltamethrin showed lethal effects against the SAPW at different developmental stages. Abametic and spinosad were toxic for larva and adult, whereas imidacloprid was toxic for larva and pupa. However, mortality levels 
at the different developmental stages were lower than those obtained under laboratory conditions. It's possible that the efficacy of insecticides in field conditions is due to contact exposure to the insect body [45] or by degradation during absorption and plant tissue translocation [58,59]. However, while it's difficult to accurately know the amount of the insecticide absorbed by each insect, but mortality caused by these insecticides on the SAPW showed a similarity of that trend with the application of the lethal concentration $\left(\mathrm{LC}_{90}\right)$. The lethal effect of insecticides and their effectiveness have also been studied in other Curculionidae pests under field conditions with fipronil being a potent control agent for Rhynchophorus ferrugineus Oliver [60], carbaryl for Dendroctonus brevicomis LeConte [61], and deltamethrin for Sternochetus mangiferae Fabricius [62]. Other studies show the efficiency of abamectin to control Dendroctonus ponderosae Hopkins [63], spinosad on Sitophilus oryzae Linnaeus [64], and imidacloprid for Ips calligraphus Germar [65]. The results have shown that each insecticide has a different spectrum of activity related to modes of action affecting the number of larvae, pupae, and adults of the SAPW. In particular, carbaryl, fipronil, and imidacloprid are the most effective in field and that maximum efficiency from insecticide treatments should be used during these life stages. The application of these insecticides reduces one or various developmental stages of the SAPW on palms affected by the bud rot disease, suggesting that continuous applications in the canopy of the palm tree can drastically decrease the population level of this insect.

\section{Conclusions}

The potential of the six neurotoxic insecticides for managing the SAPW was studied. The toxicity of these insecticides, each with different modes of action, may efficiently control SAPW populations and reduce the insect's damage to oil palm trees with bud rot disease. Fipronil, carbaryl, deltamethrin and imidacloprid have lethal effects on larvae, pupae and adults of this insect with the potential to control its field populations. The results show that neurotoxic insecticides with different modes of action cause high mortality, reduce survivorship, and affect the insect reproduction. As such, these insecticides can be used in rotation to effectively manage SAPW populations.

Author Contributions: L.C.M., A.P.-R., F.A.R.-D., J.M.C., V.C.d.S.J., G.D.S.R., F.L.F., W.M.S., C.F.W., J.C.Z., and J.E.S. conceived, designed, and conducted the experiments. All authors analyzed the data and wrote the manuscript.

Funding: This study was funded by Brazilian research agencies "Conselho Nacional de Desenvolvimento Científico e Tecnológico" CNPq (grant number 305165/2013-5), "Coordenação de Aperfeiçoamento de Pessoal de Nível Superior" CAPES (grant number 2815/11), "Fundação de Amparo a Pesquisa do Estado de Minas Gerais" FAPEMIG (grant number APQ-01079-13), and "Programa Cooperativo sobre Proteção Florestal" PROTEF of the "Instituto de Pesquisas e Estudos Florestais" IPEF.

Acknowledgments: We thank Brisas Oil Palm Plantation (Colombia) for technical support.

Conflicts of Interest: The authors declare no conflict of interest.

\section{References}

1. Giblin-Davis, R.M.; Gerber, K.; Griffith, R. Laboratory rearing of Rhynchophorus cruentatus and R. palmarum (Coleoptera: Curculionidae). Fla. Entomol. 1989, 72, 480-488. [CrossRef]

2. Jaffé, K.; Sánchez, P.; Cerda, H.; Hernández, J.V.; Jaffé, R.; Urdaneta, N.; Guerra, G.; Martínez, R.; Miras, B. Chemical ecology of the palm weevil Rhynchophorus palmarum (L.) (Coleoptera: Curculionidae): Attraction to host plants and to a male-produced aggregation pheromone. J. Chem. Ecol. 1993, 19, 1703-1720. [CrossRef]

3. Hagley, E.A.C. The role of the palm weevil, Rhynchophorus palmarum as a vector of the red ring disease of coconuts. I. Results of preliminary investigations. J. Econ. Entomol. 1963, 56, 375-380. [CrossRef]

4. Rochat, D.; Malosse, C.; Lettere, M.; Ducrot, P.H.; Zagatti, P.; Renou, M.; Descoins, C. Male-produced aggregation pheromone of the American palm weevil, Rhynchophorus palmarum (L.) (Coleoptera, Curculionidae): Collection, identification, electrophysiogical activity, and laboratory bioassay. J. Chem. Ecol. 1991, 17, 2127-2141. [CrossRef] 
5. Plata-Rueda, A.; Martínez, L.C.; Fernandes, F.L.; Ramalho, F.S.; Zanuncio, J.C.; Serrão, J.E. Interaction between the Bud Rot disease of oil palm and Rhynchophorus palmarum (Coleoptera: Curculionidae). J. Econ. Entomol. 2016, 109, 962-965. [CrossRef] [PubMed]

6. Torres, G.A.; Sarria, G.A.; Varón, F.; Coffey, M.D.; Elliott, M.L.; Martínez, G. First report of bud rot caused by Phytophthora palmivora on African oil palm in Colombia. Plant Dis. 2010, 94, 1163. [CrossRef]

7. De Franqueville, H. Oil palm bud rot in Latin America. Exp. Agric. 2003, 39, 225-240. [CrossRef]

8. Swinburne, T.R. Fatal yellows, bud rot and spear rot of African oil palm-A comparison of the symptoms of these diseases in Brazil, Ecuador and Colombia. Planter 1993, 69, 15-23.

9. Martínez, L.C.; Plata-Rueda, A. Lepidoptera vectors of Pestalotiopsis fungal disease: First records in oil palm plantations from Colombia. Int. J. Trop. Insect Sci. 2013, 33, 239-246. [CrossRef]

10. Martínez, L.C.; Plata-Rueda, A.; Serrao, J.E.; Zanuncio, J.C. Life history traits and damage potential of an invasive pest Acharia fusca (Lepidoptera: Limacodidae) on oil palm. Ann. Entomol. Soc. Am. 2014, 107, 1086-1093. [CrossRef]

11. Martínez, L.C.; Plata-Rueda, A.; Zanuncio, J.C.; Ribeiro, G.T.; Serrao, J.E. Effects of temperature on the development of Stenoma impressella (Lepidoptera: Elachistidae) on oil palm in Colombia. Fla. Entomol. 2014, 97, 1805-1811. [CrossRef]

12. Gitau, C.W.; Gurr, G.M.; Dewhurst, C.F.; Fletcher, M.J.; Mitchell, A. Insect pests and insect-vectored diseases of palms. Austral Entomol. 2009, 48, 328-342. [CrossRef]

13. Oehlschlager, A.C.; Chinchilla, C.; Castillo, G.; Gonzalez, L. Control of red ring disease by mass trapping of Rhynchophorus palmarum (Coleoptera: Curculionidae). Fla. Entomol. 2002, 85, 507-513. [CrossRef]

14. Oehlschlager, A.C. Palm weevil pheromones-discovery and use. J. Chem. Ecol. 2016, 42, 617-630. [CrossRef]

15. Moura, J.I.L.; Mariau, D.; Delabie, J.H.C. Eficiência de Paratheresia menezesi Townsend (Diptera: Tachinidae) no controle biológico natural de Rhynchophorus palmarum (L.) (Coleoptera: Curculionidae). Oléagineux 1993, 48, 219-223.

16. Moura, J.I.; Toma, R.; Sgrillo, R.B.; Delabie, J.H. Natural efficiency of parasitism by Billaea rhynchophorae (Blanchard) (Diptera: Tachinidae) for the control of Rhynchophorus palmarum (L.) (Coleoptera: Curculionidae). Neotrop. Entomol. 2006, 35, 273-274. [CrossRef] [PubMed]

17. Howard, F.W.; Giblin-Davis, R.; Moore, D.; Abad, R. Insects on Palms; Cabi: London, UK, 2001; 400p.

18. Martínez, O.L.; Plata-Rueda, A.; Martínez, L.C. Oil palm plantations as an agroecosystem: Impact on integrated pest management and pesticide use. Outlooks Pest Manag. 2013, 24, 225-229. [CrossRef]

19. Giblin-Davis, R.M.; Howard, F.W. Vulnerability of stressed palms to attack by Rhynchophorus cruentatus (Coleoptera: Curculionidae) and insecticidal control of the pest. J. Econ. Entomol. 1989, 82, 1185-1190. [CrossRef]

20. Llácer, E.; Dembilio, O.; Jacas, J.A. Evaluation of the efficacy of an insecticidal paint based on chlorpyrifos and pyriproxyfen in a micro-encapsulated formulation against the red palm weevil, Rhynchophorus ferrugineus. J. Econ. Entomol. 2010, 103, 402-408. [CrossRef]

21. Sparks, T.C.; Nauen, R. IRAC: Mode of action classification and insecticide resistance management. Pestic. Biochem. Physiol. 2015, 121, 122-128. [CrossRef]

22. Environmental Protection Agency, EPA's Pesticides Industry Sales and Usage, 2006 and 2007 Market Estimates. 2011. Available online: http://www.epa.gov/oppbead1/pestsales/ (accessed on 1 February 2011).

23. Horowitz, A.R.; Mendelson, Z.; Ishaaya, I. Effect of abamectin mixed with mineral oil on the sweetpotato whitefly (Homoptera: Aleyrodidae). J. Econ. Entomol. 1997, 90, 349-353. [CrossRef]

24. Huang, J.F.; Tian, M.; Lv, C.J.; Li, H.Y.; Zhong, G.H. Preliminary studies on induction of apoptosis by abamectin in Spodoptera frugiperda (Sf9) cell line. Pestic. Biochem. Physiol. 2011, 100, 256-263. [CrossRef]

25. Martínez, L.C.; Plata-Rueda, A.; Zanuncio, J.C.; Serrão, J.E. Comparative toxicity of six insecticides on the rhinoceros beetle (Coleoptera: Scarabaeidae). Fla. Entomol. 2014, 97, 1056-1062. [CrossRef]

26. Zinkl, J.G.; Shea, P.J.; Nakamoto, R.J.; Callman, J. Brain cholinesterase activity of rainbow trout poisoned by carbaryl. Bull. Environ. Contam. Toxicol. 1987, 38, 29-35. [CrossRef]

27. He, F. Neurotoxic effects of insecticides-current and future research: A review. Neurotoxicology 2000, 21, 829-835.

28. Pope, C.; Karanth, S.; Liu, J. Pharmacology and toxicology of cholinesterase inhibitors: Uses and misuses of a common mechanism of action. Environ. Toxicol. Pharmacol. 2005, 19, 433-446. [CrossRef] [PubMed] 
29. Bloomquist, J.R.; Miller, T.A. Sodium channel neurotoxins as probes of the knockdown resistance mechanism. Neurotoxicology 1986, 7, 217-224.

30. Soderlund, D.M.; Bloomquist, J.R. Neurotoxic actions of pyrethroid insecticides. Annu. Rev. Entomol. 1989, 34, 77-96. [CrossRef]

31. Athanassiou, G.G.; Papagregoriou, A.S.; Buchelos, C.T. Insecticidal and residual effect of three pyrethroids against Sitophilus oryzae (L.) (Coleoptera: Curculionidae) on stored wheat. J. Stored Prod. Res. 2004, 40, 289-297. [CrossRef]

32. Cole, L.M.; Nicholson, R.A.; Casida, J.E. Action of phenylpyrazole insecticides at the GABAgated chloride channel. Pestic. Biochem. Physiol. 1993, 46, 47-54. [CrossRef]

33. Hainzl, D.; Casida, J.E. Fipronil insecticide: Novel photochemical desulfinylation with retention of neurotoxicity (insecticide action and environmental persistence). Proc. Natl. Acad. Sci. USA 1996, 93, 12764-12767. [CrossRef] [PubMed]

34. Durham, E.W.; Siegfried, B.D.; Scharf, M.E. In vivo and in vitro metabolism of fipronil by larvae of the European corn borer Ostrinia nubilalis. Pest Manag. Sci. 2002, 58, 799-804. [CrossRef] [PubMed]

35. Matsuda, K.; Buckingham, S.D.; Kleier, D.; Rauh, J.J.; Grauso, M.; Sattelle, D.B. Neonicotinoids: Insecticides acting on insect nicotinic acetylcholine receptors. Trends Pharmacol. Sci. 2001, 22, 573-580. [CrossRef]

36. Llácer, E.; Negre, M.; Jacas, J.A. Evaluation of an oil dispersion formulation of imidacloprid as a drench against Rhynchophorus ferrugineus (Coleoptera, Curculionidae) in young palm trees. Pest Manag. Sci. 2012, 68, 878-882. [CrossRef] [PubMed]

37. Martínez, L.C.; Plata-Rueda, A.; Gonçalves, W.G.; Freire, A.F.P.A.; Zanuncio, J.C.; Bozdoğan, H.; Serrão, J.E. Toxicity and cytotoxicity of the insecticide imidacloprid in the midgut of the predatory bug, Podisus nigrispinus. Ecotoxicol. Environ. Saf. 2019, 167, 69-75. [CrossRef] [PubMed]

38. Salgado, V.L. Studies on the mode of action of spinosad: Insect symptoms and physiological correlates. Pestic. Biochem. Physiol. 1998, 60, 91-102. [CrossRef]

39. Crouse, G.D.; Sparks, T.C.; Schoonover, J.; Gifford, J.; Dripps, J.; Bruce, T.; Larson, L.L.; Garlich, J.; Hatton, C.; Hill, R.L.; et al. Recent advances in the chemistry of spinosyns. Pest Manag. Sci. 2001, 57, 177-185. [CrossRef]

40. Orr, N.; Shaffner, A.J.; Richey, K.; Crouse, G.D. Novel mode of action of spinosad: Receptor binding studies demonstrating lack of interaction with known insecticidal target sites. Pestic. Biochem. Physiol. 2009, 95, 1-5. [CrossRef]

41. Martínez, G.; Arias, N.A.; Sarria, G.A.; Torres, G.A.; Varón, F.; Noreña, C.; Salcedo, S.; Aya, H.; Ariza, J.G.; Aldana, R.; et al. Manejo Integrado de la pudrición del cogollo (PC) de la palma de aceite (No. D-1768); Centro de Investigación en Palma de Aceite, Cenipalma [Colombia] Federación Nacional de Cultivadores de Palma de Aceite, Fedepalma [Colombia] Servicio Nacional de Aprendizaje, SENA Sociedad de Agricultores de Colombia, SAC: Bogotá, Colombia, 2009; pp. 1-24.

42. Finney, D.J. Probit Analysis; Cambridge University Press: Cambridge, UK, 1964; 333p.

43. Originlab Corporation. OriginPro V. 9.1.0 SR2 B87; Originlab Corporation: Northampton, MA, USA, 2013; 210p.

44. SAS Institute. The SAS System for Windows, Release 9.0; SAS Institute: Cary, NC, USA, 2002; 222p.

45. Plata-Rueda, A.; Martínez, L.C.; Dos Santos, M.H.; Fernandes, F.L.; Wilcken, C.F.; Soares, M.A.; Serrão, J.E.; Zanuncio, J.C. Insecticidal activity of garlic essential oil and their constituents against the mealworm beetle, Tenebrio molitor Linnaeus (Coleoptera: Tenebrionidae). Sci. Rep. 2017, 7, 46406. [CrossRef] [PubMed]

46. Amaral, K.D.; Martínez, L.C.; Lima, M.A.P.; Serrão, J.E.; Della Lucia, T.M.C. Azadirachtin impairs egg production in Atta sexdens leaf-cutting ant queens. Environ. Pollut. 2018, 243, 809-814. [CrossRef] [PubMed]

47. Martínez, L.C.; Plata-Rueda, A.; Zanuncio, J.C.; Serrão, J.E. Bioactivity of six plant extracts on adults of Demotispa neivai (Coleoptera: Chrysomelidae). J. Insect Sci. 2015, 15. [CrossRef] [PubMed]

48. Martínez, L.C.; Plata-Rueda, A.; Agudelo, O. Efficacy of insecticides on Leptopharsa gibbicarina Froeschner (Hemiptera: Tingidae) applied by root Absorption technique in oil palm. Persian Gulf Crop Prot. 2013, 2, $10-17$.

49. Clark, D.C.; Haynes, K.F. Sublethal effects of cypermethrin on chemical communication, courtship, and oviposition in the cabbage looper (Lepidoptera: Noctuidae). J. Econ. Entomol. 1992, 85, 1771-1778. [CrossRef]

50. Knight, A.L.; Flexner, L. Disruption of mating in codling moth (Lepidoptera: Tortricidae) by chlorantranilipole, an anthranilic diamide insecticide. Pest Manag. Sci. 2007, 63, 180-189. [CrossRef] [PubMed] 
51. Bao, H.; Liu, S.; Gu, J.; Wang, X.; Liang, X.; Liu, Z. Sublethal effects of four insecticides on the reproduction and wing formation of brown planthopper, Nilaparvata lugens. Pest Manag. Sci. 2009, 65, 170-174. [CrossRef] [PubMed]

52. Alford, R.A.; Holmes, J.A. Sublethal effects of carbaryl, aminocarb, fenitrothion, and Bacillus thuringiensis on the development and fecundity of the spruce budworm (Lepidoptera: Tortricidae). J. Econ. Entomol. 1986, 79, 31-34. [CrossRef]

53. Vojoudi, S.; Saber, M.; Hejazi, M.J.; Talaei-Hassanloui, R. Toxicity of chlorpyrifos, spinosad and abamectin on cotton bollworm, Helicoverpa armigera and their sublethal effects on fecundity and longevity. Bull. Insectol. 2011, 64, 189-193.

54. Widiarta, I.N.; Matsumura, M.; Suzuki, Y.; Nakasuji, F. Effects of sublethal doses of imidacloprid on the fecundity of green leafhoppers, Nephotettix spp. (Hemiptera: Cicadellidae) and their natural enemies. Appl. Entomol. Zool. 2001, 36, 501-507. [CrossRef]

55. Hui, W.; Juan, W.; Li, H.S.; Dai, H.G.; Gu, X.J. Sub-lethal effects of fenvalerate on the development, fecundity, and juvenile hormone esterase activity of diamondback moth, Plutella xylostella (L.). Agric. Sci. China 2010, 9, 1612-1622.

56. Charmillot, P.J.; Pasquier, D.; Salamin, C.; Ter-Hovannesyan, A. Ovicidal and larvicidal effectiveness of insecticides applied by dipping apples on the small fruit tortrix Grapholita lobarzewskii. Pest Manag. Sci. 2007, 63, 677-681. [CrossRef]

57. Hoffmann, E.J.; Middleton, S.M.; Wise, J.C. Ovicidal activity of organophosphate, oxadiazine, neonicotinoid and insect growth regulator chemistries on the northern strain plum curculio, Conotrachelus nenuphar. J. Insect Sci. 2008, 8. [CrossRef]

58. Van Eerd, L.L.; Hoagland, R.E.; Zablotowicz, R.M.; Hall, J.C. Pesticide metabolism in plants and microorganisms. Weed Sci. 2003, 51, 472-495. [CrossRef]

59. Buchholz, A.; Nauen, R. Translocation and translaminar bioavailability of two neonicotinoid insecticides after foliar application to cabbage and cotton. Pest Manag. Sci. 2002, 58, 10-16. [CrossRef] [PubMed]

60. Aljabr, A.M.; Rizwan-ul-Haq, M.; Hussain, A.; Al-Mubarak, A.I.; AL-Ayied, H.Y. Establishing midgut cell culture from Rhynchophorus ferrugineus (Olivier) and toxicity assessment against ten different insecticides. In Vitro Cell. Dev. Biol.-Anim. 2014, 50, 296-303. [CrossRef] [PubMed]

61. Fettig, C.J.; Allen, K.K.; Borys, R.R.; Christopherson, J.; Dabney, C.P.; Eager, T.J.; Gibson, K.E.; Hebertson, E.G.; Long, D.F.; Munson, A.S.; et al. Effectiveness of bifenthrin (Onyx) and carbaryl (Sevin SL) for protecting individual, high-value conifers from bark beetle attack (Coleoptera: Curculionidae: Scolytinae) in the western United States. J. Econ. Entomol. 2006, 99, 1691-1698. [CrossRef] [PubMed]

62. Verghese, A.; Nagaraju, D.K.; Vasudev, V.; Jayanthi, P.K.; Madhura, H.S.; Stonehouse, J.M. Effectiveness of insecticides of synthetic, plant and animal origin against the mango stone weevil, Sternochetus mangiferae (Fabricius) (Coleoptera: Curculionidae). Crop Prot. 2005, 24, 633-636. [CrossRef]

63. Fettig, C.J.; Grosman, D.M.; Munson, A.S. Efficacy of abamectin and tebuconazole injections to protect lodgepole pine from mortality attributed to mountain pine beetle (Coleoptera: Curculionidae) attack and progression of blue stain fungi. J. Entomol. Sci. 2013, 48, 270-278. [CrossRef]

64. Getchell, A.I.; Subramanyam, B. Immediate and delayed mortality of Rhyzopertha dominica (Coleoptera: Bostrichidae) and Sitophilus oryzae (Coleoptera: Curculionidae) adults exposed to spinosad-treated commodities. J. Econ. Entomol. 2008, 101, 1022-1027. [CrossRef]

65. Grosman, D.M.; Upton, W.W. Efficacy of systemic insecticides for protection of loblolly pine against southern pine engraver beetles (Coleoptera: Curculionidae: Scolytinae) and wood borers (Coleoptera: Cerambycidae). J. Econ. Entomol. 2006, 99, 94-101. [CrossRef] [PubMed]

(C) 2019 by the authors. Licensee MDPI, Basel, Switzerland. This article is an open access article distributed under the terms and conditions of the Creative Commons Attribution (CC BY) license (http://creativecommons.org/licenses/by/4.0/). 